\title{
LONG-TERM NOISE MEASUREMENTS AND HARMONICA INDEX AS A WAY OF RAISING PUBLIC AWARENESS ABOUT TRAFFIC NOISE IN THE CITY OF NIŠ
}

\author{
UDC 502.14:534.8
}

\author{
Momir Prašćević ${ }^{1}$, Darko Mihajlov ${ }^{1}$, Dragan Cvetković ${ }^{1}$, \\ Aleksandar Gajicki ${ }^{2}$ \\ ${ }^{1}$ University of Niš, Faculty of Occupational Safety in Niš, Serbia \\ ${ }^{2}$ Institute of Transportation CIP, Belgrade, Serbia
}

\begin{abstract}
Environmental noise level monitoring in Serbia is performed in several cities and it is pursuant to the Law on Environmental Noise Protection and the accompanying regulations. Although these regulations are in accordance with the national standards, the methodology of noise monitoring varies in different cities. The issues which differ include the following: the number of measurement spots, the number of daily, weekly, and monthly measurement intervals, the duration of measurement intervals, measurement parameters and noise indicators used for noise evaluation. Different measurement procedures are the consequence of diverse city configurations, traffic structure, traffic flow, locations of noise-sensitive objects, as well as diverse contribution of noise sources. The road traffic noise level monitoring in the City of Nis has been organized from 1995 until today based on short-term measurements. The values of noise indicators are calculated based on these short-term measurements. The two newly purchased noise monitoring terminals by the Noise and Vibration Laboratory of the Faculty of Occupational Safety in Nis, enabled the long-term noise measurements. The procedure of permanent and semi-permanent road traffic noise measurements at eight locations in the City of Nis has been carried out since January 1, 2014. The results of long-term road traffic noise measurements at the main streets of Niš city are presented in this paper as well as the possibility of their presentation in the sense of the Harmonica index.
\end{abstract}

Key words: environmental noise, road traffic noise, long-term measurement, HARMONICA index

Received April 10, 2017 / Accepted July 13, 2017

Corresponding author: Momir Prašćević

University of Niš, Faculty of Occupational Safety in Niš, Čarnojevića 10a, 18000 Niš, Serbia

E-mail: momir.prascevic@znrfak.ni.ac.rs 


\section{INTRODUCTION}

Noise pollution caused by road traffic represents a major problem in the environment of most urban areas. However, the problem of road traffic noise has not been approached properly so far, and not enough attention has been paid to it in spite of the fact that it has a great impact on the quality of life of the endangered population. Reasons for such an approach could be found in the definition of noise as a subjective experience of various external events, in its specific character, as well as in the difficulties connected to relating the causes with the effects it has on general health.

The latest data related to the environmental noise pollution [1], collected from the first round of strategic noise mapping of the European Union agglomerations, indicate that $54 \%$ of the population in urban areas $(56,001,200$ inhabitants) is exposed to Lden noise levels above $55 \mathrm{~dB}$, whereas $15 \%$ of the population $(15,754,500$ inhabitants) is exposed to Lden noise levels above $65 \mathrm{~dB}$. In addition to this, additional $33,437,244$ inhabitants outside agglomerations live in areas where Lden noise levels exceed $55 \mathrm{~dB}$ and 7,657,083 live in areas where Lden noise levels exceed $65 \mathrm{~dB}$. Out of the total of $89,438,444$ inhabitants exposed to Lden noise levels above $55 \mathrm{~dB}$, almost 89 million are exposed to the traffic noise [1].

The conditions related to noise pollution in the city of Niš are in many ways similar to the conditions in other urban environments. Collecting information on traffic characteristics and noise levels and updating it over a longer period has proven to be crucial to the evaluation and management of environmental noise. Furthermore, measurement and evaluation of traffic noise are important activities which may result in the development of efficient methods for noise control.

Data on traffic noise levels in the city of Nis have been systematically collected and analyzed through the project of monitoring the noise level during a number of years starting from 1995 [2-5]. The road traffic noise level monitoring was based on short-term monitoring.

The obtained results give us an insight into the current condition of the noise level at specific locations, allowing us to compare them to previous measurement results and use this to evaluate tendencies related to possible changes in the future.

Two newly purchased noise monitoring terminals in Noise and Vibration Laboratory enable the long-term noise measurements.

The procedure of permanent and semi-permanent road traffic noise monitoring, starting from January 1, 2014 according to guidelines given in standards SRPS ISO 1996-1 [6] and SRPS ISO 1996-2 [7] and IMAGINE document [8] has been carried out eight locations.

The first results of one-year long-term measurements were published in some papers [9-11]. Some of the results are available at web site http://www.znrfak.ni.ac.rs/BVLab$\mathrm{KMB} / \mathrm{KMB}-\mathrm{Home} \cdot \mathrm{html}$.

The results which were being available until the time of the paper submission are presented in the paper.

\section{MEASUREMENT LOCATIONS FOR LONG-TERM MEASUREMENTS}

The procedure of long-term measurements is realized as semi-permanent noise monitoring with different monitoring time. Semi-permanent monitoring, ranging from 
three months to two years is more cost-effective monitoring than permanent noise monitoring that includes 24 hours a day, 365 days a year noise measurements using a permanently installed noise monitoring terminal at one location [11].

Brüel\&Kjær's Environmental Noise Management System [9-11] was used for longterm noise monitoring. This system consists of Environmental Noise Management System Software, Type 7843, two Noise Monitoring Terminals (NMT), Type 3639B and one Weather Station, Type WXT520.

Both NMTs are equipped with GPRS router and GPS receiver. One of the terminals (marked as NMT-1) is equipped with weather station, which enable measurement of the following meteorological parameters: temperature, humidity, air pressure, wind velocity, wind direction and rainfall.

The procedure of long-term measurements is realized at eight measurements locations. There are different methods for the selection of measurement locations [12]. The choice of measurement locations was done in accordance with population and residential location, characteristics of land-uses and road functions and structure. The distribution of the measurement locations is given in Fig. 1.

The mark and basic information about measurement locations are given below. Network of NMT locations is shown in Fig. 1.

NMT1.1: Intersection of Kneginje Ljubice street NMT1.2: Intersection of Kralja Stefana and Generala Milojka Lešjanina street Prvovečanog street and Vožda Karađorđa street Latitude: $43^{\circ} 19^{\prime} 12.8^{\prime \prime}$

Longitude: $21^{\circ} 53$ ' $27.6^{\prime \prime}$

Altitude: $195.3 \mathrm{~m}$

Latitude: $43^{\circ} 19^{\prime} 14^{\prime \prime}$

Microphone height: $4 \mathrm{~m}$

Longitude: $21^{\circ} 54^{\prime} 01^{\prime \prime}$

Mounting type: the lighting pole

Altitude: $197 \mathrm{~m}$

Microphone height: $4 \mathrm{~m}$

NMT2.1: Primary school "Vožd Karađorđe"

Mounting type: the lighting pole near Vožda Karađorđa street

NMT2.2: Faculty of Medicine near Dr Zorana

Đinđića street

Latitude: $43^{\circ} 19^{\prime} 13^{\prime \prime}$

Latitude: $43^{\circ} 19^{\prime} 12^{\prime \prime}$

Longitude: $21^{\circ} 54^{\prime} 13.2^{\prime \prime}$

Altitude: 196.8

Longitude: $21^{\circ} 53^{\prime} 27^{\prime}$ '

Altitude: 197.1

Microphone height: $4 \mathrm{~m}$

Mounting type: the lighting pole

Microphone height: $4 \mathrm{~m}$

Mounting type: the separate pole

NMT2.3: Residential building near Knjaževačka NMT2.4: Commercial building near railway street

Latitude: $43^{\circ} 19^{\prime} 46^{\prime \prime}$

Longitude: $21^{\circ} 55^{\prime} 58^{\prime \prime}$

Altitude: 212

Niš-Sofia-Niš

Latitude: $43^{\circ} 18^{\prime} 46^{\prime \prime}$

Longitude: $21^{\circ} 53$ ' $36^{\prime \prime}$

Altitude: 205

Microphone height: $4 \mathrm{~m}$

Microphone height: $4 \mathrm{~m}$

Mounting type: façade

Mounting type: facade

NMT2.5: Day nursery "Bamby" near Bulevar

Nemanjića street

Latitude: $43^{\circ} 19^{\prime} 26^{\prime \prime}$

NMT2.6: Municipality building near 12. februar street

Latitude: $43^{\circ} 20^{\prime} 2.7^{\prime \prime}$

Longitude: $21^{\circ} 54^{\prime} 31^{\prime \prime}$

Longitude: $21^{\circ} 52^{\prime} 51.9$ '

Altitude: 196

Altitude: 206

Microphone height: $4 \mathrm{~m}$

Microphone height: $4 \mathrm{~m}$

Mounting type: the lighting pole

Mounting type: the lighting pole 


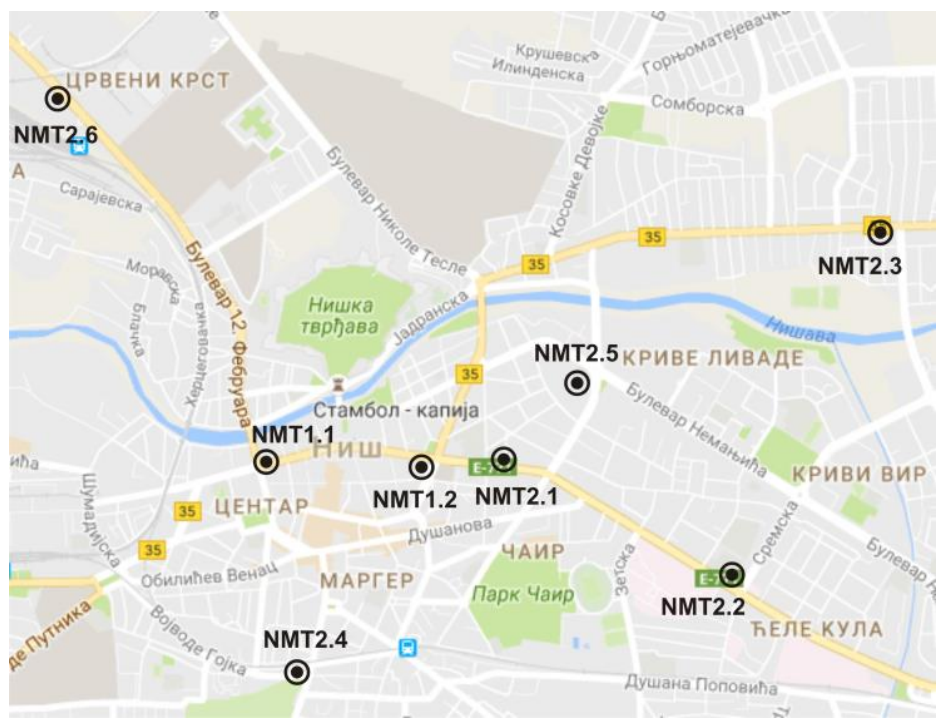

Fig. 1 Network of NMT locations

\section{RESULTS OF ROAD TRAFFIC NOISE MONITORING}

Monthly values of noise indicators for all locations as well as the results of statistical analysis (energetic mean value, standard deviation and maximum deviation of individual values from the energetic mean value) are shown in Table 1 - Table 9.

The main values of noise indicators for all locations are shown in Fig. 2.

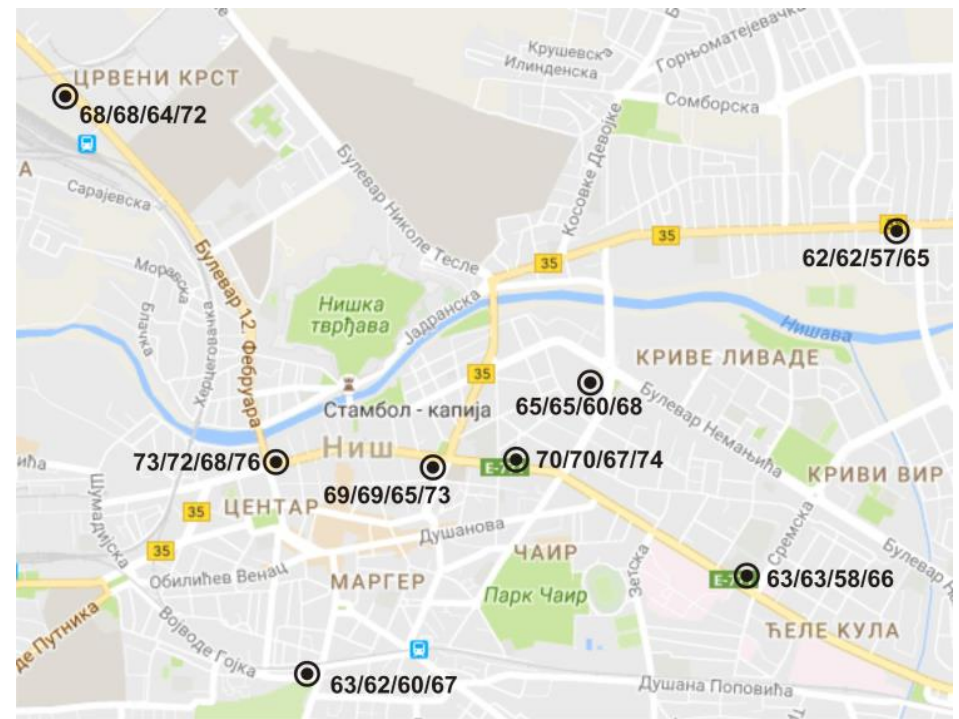

Fig. 2 The values of $\mathrm{L}_{\text {day }} / \mathrm{L}_{\text {evening }} / \mathrm{L}_{\text {night }} / \mathrm{L}_{\text {den }}$ in $\mathrm{dB}$ 
Table 1 The monthly noise indicators in $\mathrm{dB}$ for NMT-1.1

\begin{tabular}{lrrrrl}
\hline & $L_{\mathrm{d}}$ & $L_{\mathrm{e}}$ & $L_{\mathrm{n}}$ & $L_{\text {den }}$ & $L_{\text {eq,total }}$ \\
\hline January 2014 & 73.1 & 71.9 & 67.9 & 75.9 & 71.7 \\
February 2014 & 73.1 & 71.9 & 67.7 & 75.8 & 71.7 \\
March 2014 & 73.3 & 72.1 & 67.9 & 76.0 & 71.9 \\
April 2014 & 73.4 & 72.4 & 68.3 & 76.3 & 72.0 \\
May 2014 & 73.3 & 72.3 & 68.1 & 76.2 & 71.9 \\
June 2014 & 73.0 & 72.0 & 68.1 & 76.0 & 71.7 \\
July 2014 & 72.8 & 72.2 & 67.8 & 75.8 & 71.5 \\
August 2014 & 72.7 & 71.9 & 68.2 & 76.0 & 71.5 \\
September 2014 & 73.1 & 72.0 & 67.9 & 75.9 & 71.7 \\
October 2014 & 73.2 & 72.1 & 68.0 & 76.0 & 71.9 \\
November 2014 & 73.0 & 72.0 & 67.6 & 75.7 & 71.6 \\
December 2014 & 73.3 & 72.4 & 68.2 & 76.2 & 72.0 \\
mean value & $\mathbf{7 3 . 1}$ & $\mathbf{7 2 . 1}$ & $\mathbf{6 8 . 0}$ & $\mathbf{7 6 . 0}$ & $\mathbf{7 1 . 8}$ \\
o & 0.20 & 0.17 & 0.22 & 0.17 & 0.18 \\
max. deviation & 0.4 & 0.3 & 0.4 & 0.3 & 0.3 \\
\hline
\end{tabular}

Table 2 The monthly noise indicators in $\mathrm{dB}$ for NMT-1.1

\begin{tabular}{|c|c|c|c|c|c|}
\hline & $L_{\mathrm{d}}$ & $L_{\mathrm{e}}$ & $L_{\mathrm{n}}$ & $L_{\mathrm{den}}$ & $L_{\text {eq,total }}$ \\
\hline January 2015 & 72.8 & 71.4 & 68.5 & 76.0 & 71.5 \\
\hline February 2015 & 72.8 & 71.8 & 67.4 & 75.5 & 71.4 \\
\hline March 2015 & 73.2 & 72.1 & 67.8 & 75.9 & 71.8 \\
\hline April 2015 & 72.7 & 71.6 & 67.3 & 75.4 & 71.3 \\
\hline May 2015 & 72.5 & 71.4 & 67.3 & 75.3 & 71.2 \\
\hline June 2015 & 72.5 & 71.7 & 68.0 & 75.8 & 71.3 \\
\hline July 2015 & 72.1 & 71.3 & 67.5 & 75.3 & 70.9 \\
\hline August 2015 & 72.1 & 71.3 & 67.7 & 75.4 & 70.9 \\
\hline September 2015 & 72.6 & 71.5 & 67.4 & 75.4 & 71.3 \\
\hline October 2015 & 73.1 & 72.0 & 67.8 & 75.9 & 71.7 \\
\hline November 2015 & 72.9 & 71.6 & 67.7 & 75.7 & 71.5 \\
\hline December 2015 & 73.0 & 72.0 & 69.3 & 76.7 & 71.9 \\
\hline mean value & 72.7 & 71.6 & 67.8 & 75.7 & 71.4 \\
\hline$\sigma$ & 0.35 & 0.28 & 0.58 & 0.41 & 0.31 \\
\hline max. deviation & 0.6 & 0.4 & 1.5 & 1.0 & 0.5 \\
\hline
\end{tabular}

Table 3 The monthly noise indicators in $\mathrm{dB}$ for NMT-2.6

\begin{tabular}{lccccl}
\hline & $L_{\mathrm{d}}$ & $L_{\mathrm{e}}$ & $L_{\mathrm{n}}$ & $L_{\mathrm{den}}$ & $L_{\text {eq,total }}$ \\
\hline July 2016 & 67.9 & 67.5 & 63.9 & 71.5 & 66.9 \\
August 2016 & 68.2 & 67.9 & 64.1 & 71.8 & 67.1 \\
September 2016 & 68.7 & 69.6 & 64.0 & 72.3 & 67.8 \\
mean value & $\mathbf{6 8 . 3}$ & $\mathbf{6 8 . 3}$ & $\mathbf{6 4 . 0}$ & $\mathbf{7 1 . 9}$ & $\mathbf{6 7 . 3}$ \\
$\boldsymbol{\sigma}$ & 0.40 & 1.12 & 0.10 & 0.40 & 0.47 \\
max. deviation & 0.4 & 1.3 & 0.1 & 0.4 & 0.5 \\
\hline
\end{tabular}


Table 4 The monthly noise indicators in $\mathrm{dB}$ for NMT-1.2

\begin{tabular}{|c|c|c|c|c|c|}
\hline & $L_{\mathrm{d}}$ & $L_{\mathrm{e}}$ & $L_{\mathrm{n}}$ & $L_{\mathrm{den}}$ & $L_{\text {eq,total }}$ \\
\hline January 2016 & 69.4 & 69.3 & 65.8 & 73.4 & 68.5 \\
\hline February 2016 & 69.2 & 68.5 & 64.8 & 72.6 & 68.1 \\
\hline March 2016 & 69.4 & 69.0 & 65.0 & 72.8 & 68.3 \\
\hline April 2016 & 69.0 & 68.7 & 64.7 & 72.5 & 67.9 \\
\hline May 2016 & 69.2 & 69.4 & 65.6 & 73.2 & 68.3 \\
\hline June 2016 & 69.0 & 69.1 & 64.9 & 72.7 & 68.0 \\
\hline July 2016 & 68.8 & 68.7 & 65.4 & 72.9 & 67.9 \\
\hline August 2016 & 68.8 & 69.1 & 67.4 & 74.2 & 68.5 \\
\hline September 2016 & 69.5 & 70.1 & 65.5 & 73.3 & 68.6 \\
\hline mean value & 69.1 & 69.1 & 65.5 & 73.1 & 68.2 \\
\hline$\sigma$ & 0.26 & 0.48 & 0.82 & 0.53 & 0.27 \\
\hline max. deviation & 0.4 & 1.0 & 1.9 & 1.1 & 0.4 \\
\hline
\end{tabular}

Table 5 The monthly noise indicators in $\mathrm{dB}$ for NMT-2.1

\begin{tabular}{lccccc}
\hline & $L_{\mathrm{d}}$ & $L_{\mathrm{e}}$ & $L_{\mathrm{n}}$ & $L_{\mathrm{den}}$ & $L_{\text {eq,total }}$ \\
\hline January 2014 & 70.3 & 69.9 & 67.4 & 74.7 & 69.4 \\
February 2014 & 70.2 & 69.7 & 66.7 & 74.1 & 69.2 \\
March 2014 & 70.6 & 69.8 & 66.7 & 74.2 & 69.5 \\
April 2014 & 70.5 & 70.2 & 67.2 & 74.6 & 69.6 \\
May 2014 & 70.6 & 70.3 & 66.8 & 74.4 & 69.6 \\
June 2014 & 70.1 & 69.7 & 66.6 & 74.0 & 69.1 \\
mean value & $\mathbf{7 0 . 4}$ & $\mathbf{6 9 . 9}$ & $\mathbf{6 6 . 9}$ & $\mathbf{7 4 . 3}$ & $\mathbf{6 9 . 4}$ \\
$\boldsymbol{\sigma}$ & 0.19 & 0.26 & 0.35 & 0.26 & 0.18 \\
max. deviation & 0.3 & 0.4 & 0.5 & 0.4 & 0.3 \\
\hline
\end{tabular}

Table 6 The monthly noise indicators in $\mathrm{dB}$ for NMT-2.2

\begin{tabular}{|c|c|c|c|c|c|}
\hline & $L_{\mathrm{d}}$ & $L_{\mathrm{e}}$ & $L_{\mathrm{n}}$ & $L_{\mathrm{den}}$ & $L_{\text {eq,tota }}$ \\
\hline July 2014 & 63.5 & 63.0 & 57.6 & 66.1 & 62.2 \\
\hline August 2014 & 62.2 & 62.0 & 57.5 & 65.5 & 61.1 \\
\hline September 2014 & 63.1 & 62.5 & 57.9 & 66.0 & 61.8 \\
\hline October 2014 & 63.4 & 62.8 & 57.9 & 66.2 & 62.1 \\
\hline November 2014 & 63.3 & 62.8 & 57.9 & 66.2 & 62.1 \\
\hline December 2014 & 63.7 & 63.0 & 58.2 & 66.5 & 62.4 \\
\hline January 2015 & 62.8 & 61.7 & 57.4 & 65.5 & 61.4 \\
\hline February 2015 & 63.1 & 62.7 & 57.9 & 66.1 & 61.8 \\
\hline March 2015 & 63.6 & 63.0 & 58.3 & 66.5 & 62.3 \\
\hline mean value & 63.2 & 62.6 & 57.8 & 66.1 & 61.9 \\
\hline$\sigma$ & 0.46 & 0.47 & 0.30 & 0.36 & 0.43 \\
\hline max. deviation & 1.0 & 1.0 & 0.4 & 0.6 & 0.8 \\
\hline
\end{tabular}


Table 7 The monthly noise indicators in $\mathrm{dB}$ for NMT-2.3

\begin{tabular}{lrrrrl}
\hline & $L_{\mathrm{d}}$ & $L_{\mathrm{e}}$ & $L_{\mathrm{n}}$ & $L_{\text {den }}$ & $L_{\text {eq.total }}$ \\
\hline April 2015 & 62.6 & 61.9 & 57.2 & 65.4 & 61.2 \\
May 2015 & 62.0 & 61.3 & 56.8 & 64.9 & 60.7 \\
June 2015 & 62.1 & 61.5 & 56.9 & 65.0 & 60.8 \\
mean value & $\mathbf{6 2 . 2}$ & $\mathbf{6 1 . 6}$ & $\mathbf{5 7 . 0}$ & $\mathbf{6 5 . 1}$ & $\mathbf{6 0 . 9}$ \\
$\boldsymbol{\sigma}$ & 0.32 & 0.31 & 0.21 & 0.26 & 0.26 \\
max. deviation & 0.4 & 0.3 & 0.2 & 0.3 & 0.3 \\
\hline
\end{tabular}

Table 8 The monthly noise indicators in $\mathrm{dB}$ for NMT-2.4

\begin{tabular}{lccccc}
\hline & $L_{\mathrm{d}}$ & $L_{\mathrm{e}}$ & $L_{\mathrm{n}}$ & $L_{\mathrm{den}}$ & $L_{\text {eq,total }}$ \\
\hline July 2015 & 62.9 & 62.2 & 60.4 & 67.4 & 62.1 \\
August 2015 & 62.1 & 61.4 & 59.8 & 66.8 & 61.3 \\
September 2015 & 63.0 & 61.8 & 58.8 & 66.4 & 61.8 \\
October 2015 & 63.7 & 61.9 & 59.2 & 66.8 & 62.3 \\
November 2015 & 63.6 & 61.2 & 59.8 & 67.0 & 62.3 \\
December 2015 & 63.8 & 62.4 & 60.6 & 67.7 & 62.7 \\
mean value & $\mathbf{6 3 . 2}$ & $\mathbf{6 1 . 8}$ & $\mathbf{5 9 . 8}$ & $\mathbf{6 7 . 0}$ & $\mathbf{6 2 . 1}$ \\
$\boldsymbol{\sigma}$ & 0.65 & 0.46 & 0.69 & 0.47 & 0.48 \\
max. deviation & 1.1 & 0.6 & 1.0 & 0.7 & 0.8 \\
\hline
\end{tabular}

Table 9 The monthly noise indicators in $\mathrm{dB}$ for NMT-2.5

\begin{tabular}{lccccl}
\hline & $L_{\mathrm{d}}$ & $L_{\mathrm{e}}$ & $L_{\mathrm{n}}$ & $L_{\mathrm{den}}$ & $L_{\mathrm{eq}, \text { total }}$ \\
\hline January 2016 & 65.5 & 64.3 & 59.8 & 68.8 & 64.2 \\
February 2016 & 65.5 & 64.8 & 59.3 & 68.2 & 64.4 \\
March 2016 & 65.7 & 64.7 & 59.4 & 68.0 & 64.2 \\
April 2016 & 65.0 & 64.5 & 59.4 & 67.6 & 63.6 \\
May 2016 & 65.2 & 65.1 & 59.6 & 68.0 & 64.0 \\
June 2016 & 64.6 & 64.9 & 59.4 & 67.8 & 63.5 \\
mean value & $\mathbf{6 5 . 3}$ & $\mathbf{6 4 . 7}$ & $\mathbf{5 9 . 5}$ & $\mathbf{6 8 . 1}$ & $\mathbf{6 4 . 0}$ \\
$\boldsymbol{\sigma}$ & 0.40 & 0.29 & 0.18 & 0.41 & 0.36 \\
max. deviation & 0.7 & 0.4 & 0.3 & 0.7 & 0.5 \\
\hline
\end{tabular}

The monthly values of noise indicators for all locations are slightly different from the energetic mean values of noise indicators for observation interval except for the case of occasional occurrences such as New Year`s celebration (NMT1.1. - December 2015), celebration of Olympic champion in water polo (NMT1.2 - August 2016).

\section{In PLACE OF CONCLUSION - NEW APPROACH FOR ENVIRONMENTAL NOISE ASSESSMENT}

It currently remains difficult for people to understand the environmental noise data due to various noise indicators that are expressed in decibel unit which is logarithmic in nature, and usually complicated to explain and relatively far-removed from perception of people. Also, the noise indicators are very often expressed in $\mathrm{dB}(\mathrm{A})$, which further complicates the understanding of noise indicators values.

Two French organizations specialized for management and organization of urban noise observatories in France, have worked on a proposal for a new index closer to the 
perception of the people $[13,14]$. They suggested a new environmental noise index called Harmonica (HARMOnised Noise Information for Citizens and Authorities) index. The Harmonica index is based on measurement data obtained by noise monitoring and take into account both the overall environmental noise load and noise peaks from sudden noise events.

The Harmonica index is calculated based on an one-hour time sample of A-weighted, equivalent continuous sound level sampled with 1 second interval, and it takes into account the two major components that affect the sound environment.

The Harmonica index is an adimensional index based on a scale of 0 to 10 . The Harmonica index is graphically represented as a triangle (BGN component) on top of a rectangle (EVT component). The rectangle represents the BGN component (background noise sub-index) and the triangle represents the EVT component (peak noise sub-index) related to noise dynamics and the number of noise peaks that emerge above the background noise and disturb the calm.

The Harmonica index is an adimensional index and the hourly Harmonica index (HHI) can be calculated by the following mathematical formula [13,14]:

where:

$$
H H I=B G N+E V T
$$

$B G N$ is background noise sub-index, and

$E V T$ is peak noise sub-index.

A component related to the background noise $[13,14]$ can be calculated as:

where:

$$
B G N=0.2 \times\left(L_{\mathrm{A} 95 \mathrm{eq}}-30\right)
$$

$L_{\mathrm{A} 95 \mathrm{eq}}$ is the background noise level during the one-hour period, where the background noise being calculated every second by the noise level exceeded $95 \%$ of the time during the previous ten minute period.

An event-related component [6], which represents the acoustic energy provided by noise peaks that emerge above the background noise, can be calculated as:

where:

$$
E V T=0.25 \times\left(L_{\text {Aeq }}-L_{\text {A95eq }}\right)
$$

$L_{\text {Aeq }}$ is the equivalent noise level during a one-hour period.

Three colors (green, orange and red) are used for color representation of the Harmonica index. The color scale is shown in Table 10.

Table 10 The color scale for Harmonica index

\begin{tabular}{lccc}
\hline \multicolumn{1}{c}{ Color } & $\begin{array}{c}\text { Day } \\
\text { (from 6 am to 10 pm) }\end{array}$ & $\begin{array}{c}\text { Night } \\
\text { (from 10 pm to 6 am) }\end{array}$ & $\begin{array}{c}\text { Harmonica } \\
\text { index score }\end{array}$ \\
\hline green & between 0 and 4 & between 0 and 3 & Quiet \\
orange & between 4 and 8 & between 3 and 7 & Noisy \\
red & over 8 & over 7 & Very noisy \\
\hline
\end{tabular}


According to the calculation procedure given above two example of Harmonica index calculation are given in Fig. 3 and Fig. 4 based on the data of the long-term noise measurements in the city of Niš.

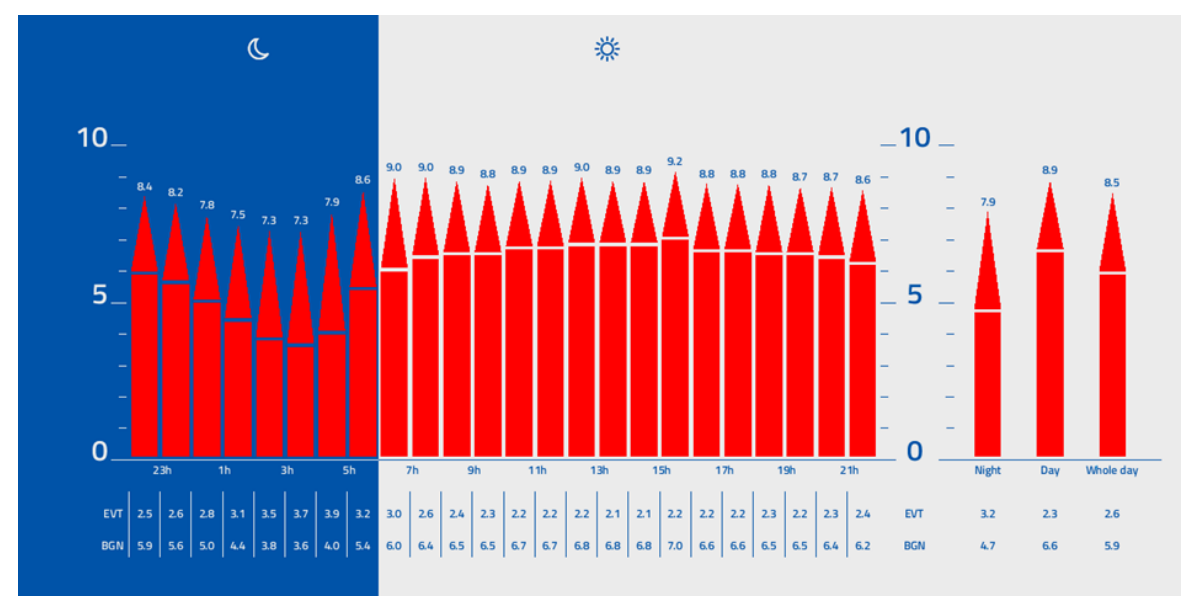

Fig. 3 The averaged hourly values of Harmonica indices for NMT-1.1 (April 20, 2015 - April 26, 2015)

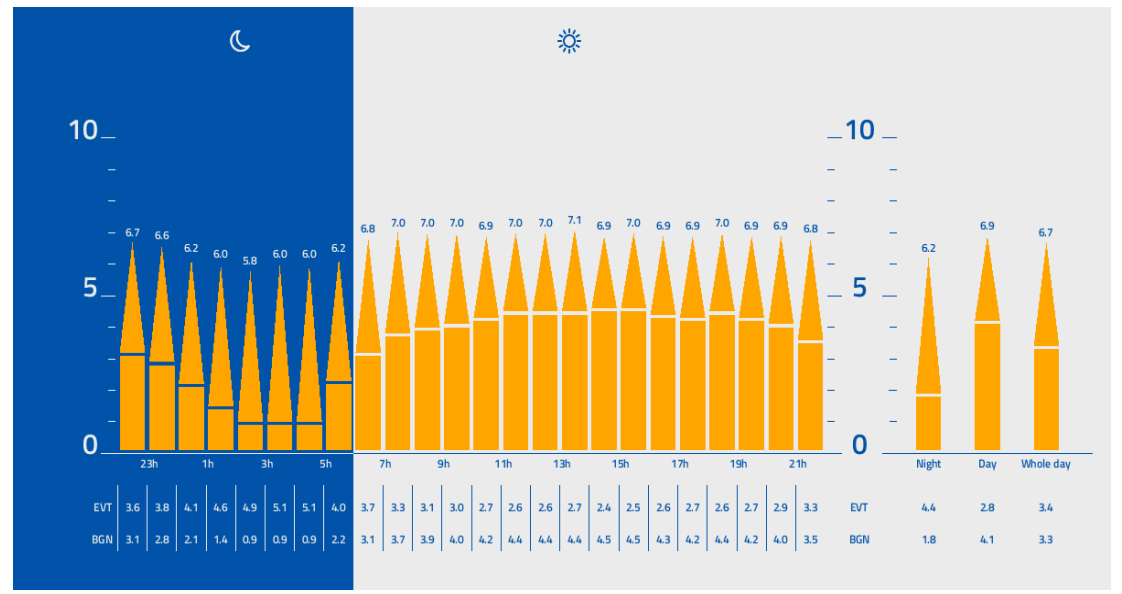

Fig. 4 The averaged hourly values of Harmonica indices for NMT-2.3 (April 20, 2015 - April 26, 2015)

The hourly values of Harmonica index as well as the average values for the day period, the night period and the entire day for period from April, 20, 2015 to April, 26, 2015 are given for NMT-1.1 and NMT-2.3 on the Fig. 3 and Fig. 4, respectively. The values of EVG and BGN sub-indices are also shown in the same figures.

According to the values of the Harmonica index, the sound environment near the location NMT-1.1 can be assessed as VERY NOISY. Also, the sound environment near the location NMT-2.3 can be assessed as NOISY. 
The Harmonica index is easier to understand than decibels because it is based on a scale of 0 to 10 . Using this index, the sound environment can be assessed as quiet, noisy or very noisy. The graphical representation of the Harmonica indices enables straightforward understanding and a more representative image of the sound environment for people's perception of environmental noise.

Acknowledgement: This research is part of the project "Development of methodology and means for noise protection from urban areas" (No. TR-037020) and "Improvement of the monitoring system and the assessment of a long-term population exposure to pollutant substances in the environment using neural networks"(No. III-43014). The authors gratefully acknowledge the financial support of the Serbian Ministry for Education, Science and Technological Development for this work.

\section{REFERENCES}

1. Licitra G., (2012), Noise mapping in EU: Models and Procedures, CRC Press, USA, 2012, p. 442. , ISBN 978-0-415-58509-5.

2. Praščević M., (1995), Systematic Environmental Noise Measurement of Nis, Proceedings of XV Yugoslav and III International Conference "Noise and Vibration in Living and Working Environment", Niš, Serbia, pp. 1995, 35-38.

3. Cvetković D., Deljanin A., Praščević M., (1997), Community noise levels survey of Nis, Proceedings of the International Congress on Noise Control Engineering "INTER NOISE", Budapest, Hungary, 1997, pp. 815-818.

4. Mihajlov D., Praščević M., Cvetkovic D., (2008), Results of the monitoring and assessment of the state of noise level in Nis in 2007, Proceedings of $21^{\text {st }}$ Conference with International Participation "Noise and Vibration", Nis, Serbia, 2008, ID: 21-23.

5. Mihajlov D., Praščević M., Cvetkovic D., (2012), An analysis of the environmental noise levels on the territory of the city of Nis, Proceedings of $23^{\text {rd }}$ National and $4^{\text {th }}$ International Conference "Noise and Vibration", Nis, Serbia, 2012, pp. 49-58.

6. SRPS ISO 1996-1: 2010, Acoustics - Description, measurement and assessment of environmental noise Part 1: Basic quantities and assessment procedures.

7. SRPS ISO 1996-2: 2010, Acoustics - Description, measurement and assessment of environmental noise Part 2: Determination of environmental noise levels.

8. IMAGINE Project, Deliverable 5, "Determination of $L_{\mathrm{den}}$ and $L_{\mathrm{night}}$ using measurements", 2011. [Online]. Available: http://www.certificacioacustica.cat/Documents/Articles/D5_IMA32TR-040510-SP08.pdf

9. Praščević M., Mihajlov D., Cvetković D., (2014), Permanent and semi-permanent noise monitoring first results in the city of Nis, Proceedings of $24^{\text {th }}$ International Conference "Noise and Vibration", ISBN: 978-86-6093-062-2, Niš, 2014, pp. 33-40.

10. Praščević M., Mihajlov D., (2014), Noise indicators determination based on long-term measurements, Facta universitatis, Series: Working and Living Environmental Protection, Vol. 11, No. 1, 2014, University of Niš, pp. 1-11.

11. Mihajlov D., Praščević M., (2015), Permanent and Semi-permanent Road Traffic Noise Monitoring in the City of Nis (Serbia), Journal of low frequency noise, vibration and active control, Vol. 34, No. 3, ISSN: 0263-0923, 2015, University of Sheffield, pp. 251-268, http://dx.doi.org/10.1260/02630923.34.3.251.

12. Doygum H., Gurun D. K., (2008), Analysing and mapping spatial and temporal dynamics of urban traffic noise pollution: a case study in Kahramanmaraş, Turkey, Environmental Monitoring and Assessment, 142, 2008, pp. 65-72.

13. Mietlicki C., Mietlicki F., Riberio C., Gaudibert P., (2014), The HARMONICA project, new tools to assess environmental noise and better inform to the public, Proceedings of Forum Acousticum, Krakow, Poland, 2014

14. Mietlicki F., Gaudibert P., (2012), The HARMONICA project (HARMOnized In-formation for Citizens and Authorities)", Proceedings of Inter-noise, New York, USA, 2012 
15. Praščević M., Mihajlov D., Cvetković D., (2015), Assessment of environmental noise by Harmonica index - case study: the city of Niš“, Applied Mechanics and Materials, Vol. 801, Trans tech publications Inc., ISBN 978-3-03835-628-8, 2015, pp 51-59.

16. Praščević M., Mihajlov D., Cvetković D., (2015), The Correlation between Harmonica Indices and Noise Indicators“, ANALELE UNIVERSIT کŢII “EFTIMIE MURGU” REŞIŢA ANUL XXII, NR. 2, ISSN 1453 7397, University of Resita, 2015, pp 306-317, http://anale-ing.uem.ro/2015/230.pdf.

\section{DUGOTRAJNA MERENJA BUKE I INDEKS "HARMONICA" KAO NAČIN JAČANJA SVESTI JAVNOSTI O SAOBRAĆAJNOJ BUCI U NIŠU}

Merenje buke u životnoj sredini se vrši u nekoliko gradova Srbije u skladu sa Zakonom o zaštiti od buke u životnoj sredini i pratećim propisima. Metodologija monitoringa buke se razlikuje u različitim gradovima iako su ovi propisi u skladu sa nacionalnim standardima. Elementi koji se razlikuju su sledeči: broj mernih tačaka, broj dnevnih, nedeljnih i mesečnih mernih intervala, trajanje mernih intervala, merni parametri i indikatori buke koji se koriste za ocenu buke. Različite merne procedure su posledica različitih konfiguracija terena, saobraćajne strukture, protoka saobrćaja, lokacije objekata osetljivih na buku kao i različitih doprinosa izvora buke. Monitoring nivoa buke drumskog saobraćaja u Nišu koji je zasnovan na kratkotrajnim merenjima se organizuje od 1995 godine do danas. Dva nova terminala za monitoring Laboratorije za buku i vibracije omogućuju dugotrajna merenja buke. Procedura permanentnih i polupermanentnih merenja buke drumskog saobraćaja se sprovodi na osam lokacija u Nišu počev od januara 2014. godine. Rezultati dugotrajnih merenja buke drumskog saobraćaja kao i mogužnost njihove prezentacije korišćenjem indeksa "Harmonica" su predstavljeni u ovom radu

Ključne reči: buka u životnoj sredini, buka drumskog saobraćaja, dugotrajno merenje, indeks "Harmonica" 